\title{
SHOREBIRD SURVEYS OF THE LAHONTAN VALLEY, NEVADA, 1986-2019, WITH RECOMMENDATIONS ON MONITORING AND MANAGEMENT
}

\author{
STANLEY SENNER and BRIAN TAVERNIA, National Audubon Society, 231 \\ West 800 South, Suite E, Salt Lake City, Utah 84101; stanley.senner@audubon.org \\ JENNI JEFFERS, Nevada Department of Wildlife, 380 West B Street, Fallon, \\ Nevada 89406
}

MONICA IGLECIA, Manomet, P. O. Box 1770, Manomet, Massachusetts 02345

BETHANY CHAGNON, Stillwater National Wildlife Refuge Complex, 1020 New River Parkway, Suite 305, Fallon, Nevada 89406

LARRY NEEL, 3145 Silver State Avenue, Fallon, Nevada 89406

ABSTRACT: Stillwater National Wildlife Refuge and Carson Lake and Pasture are the key components of the Lahontan Valley wetlands, designated in 1988 as a site of hemispheric importance in the Western Hemisphere Shorebird Reserve Network. In 1990, Congress authorized transfer of Carson Lake and Pasture from federal ownership to the state of Nevada, provided that the area be managed consistent with its designation as part of the network. To enhance protection and management of the site, and specifically to inform development of a management plan for Carson Lake and Pasture, we analyzed spring and fall surveys for shorebirds, 1986-2019, archived by the Nevada Department of Wildlife. Over the 34 years of surveys, we documented 28 species, 19 of which occurred in $\geq 50 \%$ of the years surveyed. Annual counts of all shorebirds combined exceeded 100,000 in $24 \%$ of the survey years and 20,000 in 94\%. Annual counts of the American Avocet (Recurvirostra americana) exceeded $10 \%$ (45,000 individuals) of the estimated global population in three years, and of the Long-billed Dowitcher (Limnodromus scolopaceus; 50,000 individuals) in two years. On the basis of their numbers and frequency of occurrence or status as species of national conservation concern, we identified these two species plus nine others as priorities for management. We recommend conducting more consistent surveys and identifying specific opportunities to manage water quantity and quality, vegetation, livestock grazing, or other factors to benefit shorebirds.

The arid Great Basin and more broadly the Intermountain West provide significant habitats for a variety of migrating shorebirds (Recurvirostridae, Charadriidae, and Scolopacidae), some in large numbers (Shuford et al. 2002). Thomas et al. (2013), for example, identified 18 primary and 18 secondary "key" sites for shorebirds. These primary key sites were (a) identified in Oring et al. (2000) or by the Western Hemisphere Shorebird Reserve Network 
(WHSRN), (b) supported $>5000$ shorebirds during peak migration counts, or (c) supported $>1 \%$ of the biogeographic population of a shorebird species during any one season (Thomas et al. 2013). A "biogeographic population" is defined as the entire population of a monotypic species, the entire population of a subspecies, or a discrete population of a species or subspecies that rarely if ever mixes with other populations of the same species or subspecies (www.ramsar.org/sites/default/files/documents/library/glossary_strategic framework_en.pdf). Secondary sites supported $<5000$ migrants during peak counts over one migration season during the surveys described by Shuford et al. (2002).

Many of these important sites, including closed-basin salt lakes and associated wetlands, have been degraded. Diversions and withdrawals of surface water and groundwater for human uses have affected the level, quality, and seasonality of water in the region for decades (Jehl 1994, Neel and Henry 1996, Thomas et al. 2013, Moore 2016, Wilsey et al. 2017, Wurtsbaugh et al. 2017). From 1980 to 2008 the regional climate became drier, leading to earlier streamflow and reduced water availability (Haig et al. 2019). Primarily because of increased evaporation and diversion for irrigation, from 1984-1999 to 2000-2018 the extent of surface water contracted in 18 of the Great Basin's snowmelt-fed lakes and wetlands, including Nevada's Carson Sink. In lakes the reduction was $27 \%$, in wetlands $47 \%$ (Donnelly et al. 2020).

In 1988 the Lahontan Valley wetlands complex was designated a WHSRN site of hemispheric importance because of its reported use by more than 250,000 migrant shorebirds annually, including up to 150,000 Long-billed Dowitchers (Limnodromus scolopaceus; whsrn.org/whsrn_sites/lahontanvalley-wetlands/; Neel and Henry 1996). In 1990, the Truckee-Carson Settlement Act (P.L. 101-618, Title II) authorized transfer of Carson Lake and Pasture ("Carson Lake" for short), a core part of the WHSRN site, from ownership by the federal Bureau of Reclamation to the state of Nevada, provided that the area be managed consistent with its designation as a WHSRN site. Completion of the transfer is pending in 2021 and will be followed by development of a management plan for what will become the Carson Lake and Pasture Wildlife Management Area (WMA) (A. Jenne pers. comm.).

We used the results of 34 years (1986-2019) of spring and fall surveys compiled and maintained by the Nevada Department of Wildlife (NDOW) to review the status of migrant shorebirds in the Lahontan Valley. It is timely to review the Lahontan Valley surveys, given continuing regional declines of lake and wetland habitats, the anticipated development of a Carson Lake management plan, and broader concerns about the status and future of shorebird populations in the Great Basin and beyond (e.g., Jehl 1994, Page and Gill 1994, Shuford et al. 2002, Senner et al. 2016, 2018, Rosenberg et al. 2019). Publications by Neel and Henry (1996), Chisholm and Neel (2002), and Shuford et al. (2002) drew on the NDOW data, but there have been no subsequent comprehensive analyses. Within the context of the Great Basin and with reference to the WHSRN criteria, we broadly characterize use of the Lahontan Valley by migrating shorebirds, recommend species as priorities for monitoring and management, and discuss insights into water and habitat management and future surveys. 


\section{STUDY AREA}

The Lahontan Valley is located near Fallon, Churchill County $\left(39^{\circ} 30^{\prime} \mathrm{N}\right.$, $118^{\circ} 30^{\prime} \mathrm{W}$ ), about $112 \mathrm{~km}$ east of Reno (Figure 1). This valley is the terminal delta of the Carson River within Carson Sink, and the historic Stillwater Marsh and Carson Lake are its two primary wetland areas. The Lahontan Valley wetlands WHSRN site includes Carson Lake, currently owned by the Bureau of Reclamation and co-managed by NDOW and the TruckeeCarson Irrigation District, and Stillwater NWR, managed by the U.S. Fish and Wildlife Service (USFWS). The wetlands' total combined area at the time of designation was 89,031 ha (NDOW 1988).

Before the onset of development in the 1880s, Kerley et al. (1993) estimated 60,703 ha as a "representative" value for the extent of the Lahontan wetlands, including open water and adjacent marsh. Depending on the snowpack in the Sierra Nevada, these wetlands may have contracted to as few as 10,118 ha and expanded to as many as 101,171 ha (Kerley et al. 1993). By 1993, Kerley et al. (1993) estimated that wetlands in the Lahontan Valley were only 10\% of their historical size.

In 1990, the Truckee-Carson Settlement Act authorized acquisition of sufficient water to maintain a long-term average of 10,118 ha of primary wetlands in the Lahontan Valley, including 5666 ha in Stillwater NWR, 4128 ha at Carson Lake, and 324 ha on the Fallon Paiute-Shoshone Indian Reservation (USFWS 2002). To date, acquired water rights for wetlands at Stillwater NWR, Carson Lake, and the Fallon Paiute-Shoshone Indian Reservation are sufficient to support a long-term average of about 4856 ha of primary wetlands (R. Grimes pers. comm.). Notwithstanding continuing acquisition of water rights, the Lahontan Valley continues to lose wetland habitat: Donnelly et al. (2020) showed that in Carson Sink, from 1984-1999 to 2000-2018, the extent of surface water in lakes declined by $90 \%$ and the extent of surface water in wetlands declined by $43 \%$.

Wetlands in the Lahontan Valley are typical of the saline marsh systems found in the closed basins of the Great Basin (Neel and Henry 1996, Chisholm and Neel 2002). Because this is a terminal system, the lakes and wetlands range from fresh to brackish and saline. Historically, wetlands at the upper end of Carson Lake's marsh system contained inflowing fresh water, which became increasingly saline as water moved toward the lower end at Big Water Lake in Stillwater NWR (Figure 1; Bundy 2001, Chisholm and Neel 2002). Water levels were highest during the spring flood and typically decreased as evaporation increased during summer months. When evaporation slowed, water levels increased somewhat in the fall and winter (C. Lunderstadt pers. comm.).

The historical volume and seasonality of water at Carson Lake and Stillwater NWR is now greatly altered because of upstream water use and management for agriculture and protection of endangered species (Chisholm and Neel 2002), and the timing and volume of water delivered vary from year to year (C. Lunderstadt pers. comm.). At both locations the wetlands are intensively managed, though existing infrastructure allows for water conveyance through gravity only (i.e., no pumping). At Carson Lake, management for wildlife is subordinate to other demands for the water (www.tcid.org/policies/ sectiond.pdf). To the extent there is management of water for wildlife, it tends 


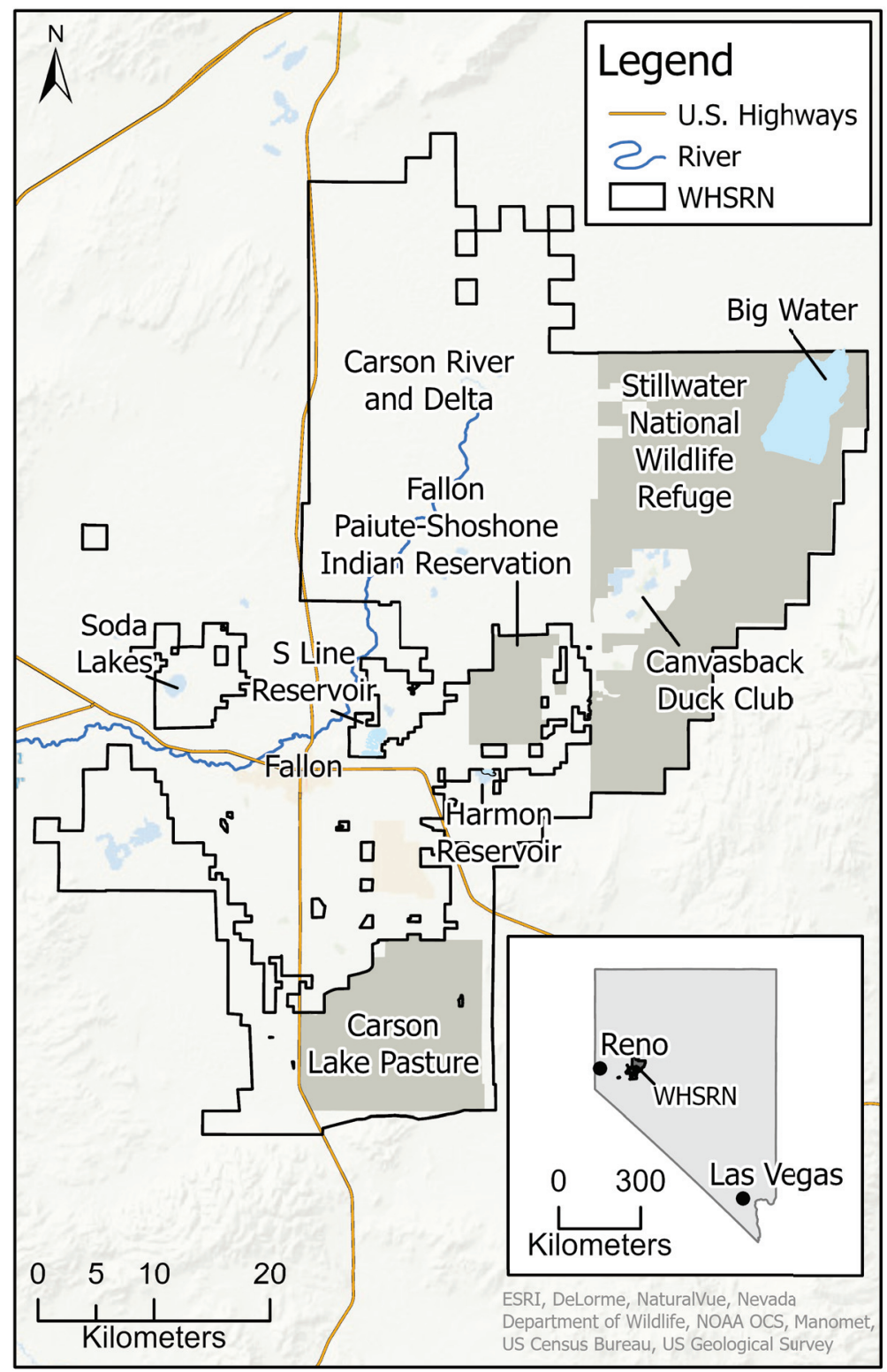

FiguRE 1. Study area, including the Lahontan Valley wetlands site in the Western Hemisphere Shorebird Reserve Network (WHSRN) and related locations. Units surveyed in $>4$ years are labeled. The Fallon Paiute-Shoshone Indian Reservation and Fallon are mentioned in the text but were not survey units. Big Water Lake, also mentioned in the text, is shown here as a geographic reference, but any surveys at that location are included within those of the Stillwater NWR/Canvasback Club unit. 
to focus on providing water to facilitate hunting for waterfowl in the fall. At Stillwater NWR, management is intended to mimic historical hydrological patterns and approximate natural habitat conditions, albeit on a scale smaller than before development and in a manner that maximizes habitat availability and biodiversity throughout the year (USFWS 2002).

\section{METHODS}

The NDOW dataset spans 34 years, 1986-2019. Biologists for NDOW conducted all the surveys at Carson Lake: L. Neel from spring 1986 through spring 2001, and J. Jeffers from fall 2001 through fall 2019. Their work was augmented by other professional biologists (e.g., W. Henry, Stillwater NWR) as well as by volunteers (e.g., from Lahontan Audubon Society), especially at Stillwater NWR and the adjacent Canvasback Club. Surveys generally followed the protocols described by Shuford et al. (2002) for the Pacific Shorebird Project, which included the Lahontan Valley from 1989 to 1995. In general, however, the surveys' effort, specific methods, and habitat conditions varied, and the details were not always recorded across the span of years and locations.

Following Shuford et al. (2002), who defined a site as a "complex of wetlands lying within the same drainage basin," we treated the wetlands in the Lahontan Valley as one site and aggregated data by season and year. This facilitates comparisons with other Great Basin sites as reported in Shuford et al. (2002). Individual locations within the Lahontan Valley where surveys were conducted are referred to here as units (e.g., Carson Lake). Each year and each spring and fall season, observers surveyed units within the Lahontan Valley wetlands known to be used by shorebirds on the basis of prior experience or recent observations. Each survey's duration generally depended on the number of shorebirds present in a unit. Seasonally and annually, observers adjusted observation points if visibility became obstructed, for example, by changes in vegetation growth. Surveys were suspended if prevailing environmental conditions, such as rainfall, prevented reliable counts. Survey units were visited once per season, and the order in which survey units were covered on each survey was opportunistic.

Observers surveyed on the ground by foot or from stopped vehicles with the aid of binoculars or spotting scopes. Some surveys were by water from airboats, which were stopped for counts of $>10$ shorebirds. Only binoculars were used for boat-based counts.

To coincide with peak migrations across the region, most surveys took place during a "specified week" in spring and fall (Neel and Henry 1996). Guided by Chisholm and Neel (2002), we classified counts in April (77 dates) and May (20) as spring surveys $(n=97)$, those in July (8 dates), August (83), and September $(15)$ as fall surveys $(n=106)$. Within a given season and year, the units surveyed were typically not all covered on the same day.

Over the years, Carson Lake and Stillwater NWR/Canvasback Club (Figure 1) received the most consistent survey coverage (Figure 2). With the exception of 2015, when Carson Lake was dry, these two units were surveyed annually. Other units surveyed in $>4$ years were Soda Lakes, S Line Reservoir, Harmon Reservoir, and Carson River and delta (Figures 1 and 2). Units 
surveyed in $\leq 4$ years were Sheckler Reservoir, Lahontan Valley, Miller Drain, Mahala Slough, Lattin's field, farm fields, and other areas.

When possible, all shorebirds were identified to species. If that was not possible, species of the genera Calidris, Limnodromus, Tringa, and Phalaropus were identified at that level. Although some Short-billed Dowitchers (Limnodromus griseus) were recorded on the surveys, they are considered rare in the Lahontan Valley (Chisholm and Neel 2002). Given the difficulty of distinguishing the Short- and Long-billed dowitchers in field surveys (Shuford et al. 2002), we combined all dowitcher observations as "dowitcher spp." and treat them as Long-billed Dowitchers for purposes of analysis and discussion. "Unknown sandpipers" are included only in the analysis of aggregated shorebirds.

Given the surveys' uncertainty and variability in methods, observer numbers, coverage, timing within a season, and measures of effort, these data do not lend themselves to rigorous statistical analysis. Hence our summary is primarily descriptive. For each species, genus, and all shorebirds combined, we pooled counts across the Lahontan Valley by year for spring and fall separately (seasonal totals) and for spring and fall together (annual total). We present seasonal and annual total counts and nonzero median and maximum total counts across all years of the study. We also report the frequency of nonzero counts by spring and fall seasons, across years, and annually (i.e., species occurring in either spring or fall) across years.

To guide recommendations on priority species for future habitat and water management, we used the following criteria: (1) observed regularly (frequency of occurrence of $\geq 50 \%$ ); (2) area of importance scores of 4 or 5 in Bird Conservation Region 9/Great Basin (Thomas et al. 2013); and (3a) median counts $\geq 100$ and maximum high counts $\geq 1000$ in either spring or fall, or

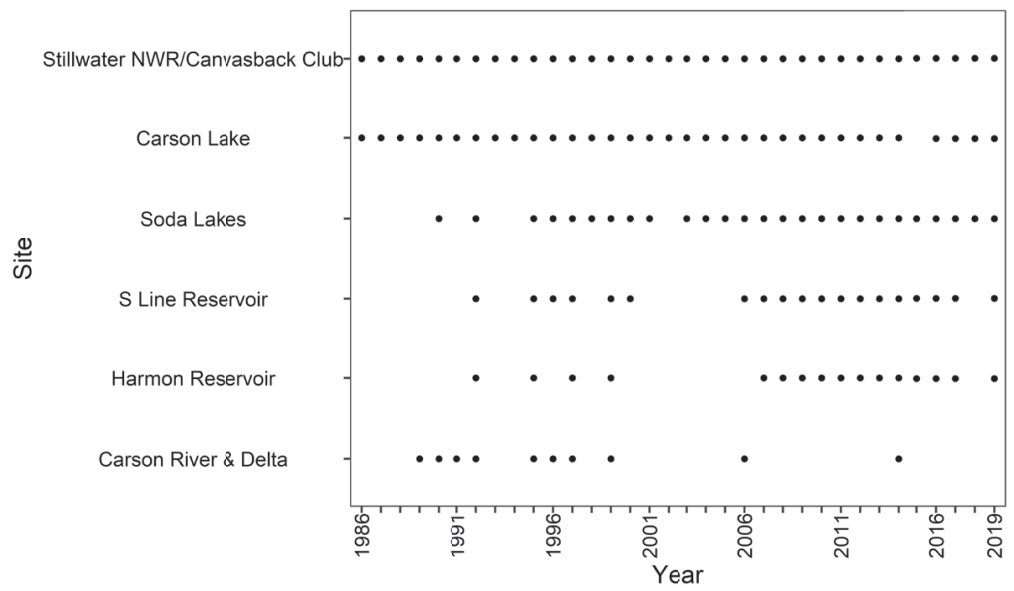

FIgURe 2. Distribution by year and unit of shorebird surveys of Lahontan Valley, in either spring or fall, 1986-2019, for units surveyed in $>4$ years. Units surveyed in $\leq 4$ years were Sheckler Reservoir, Lahontan Valley, Miller Drain, Mahala Slough, Lattin's field, and farm fields. 
(3b) identified as species of "greatest" or "high" concern by the U.S. Shorebird Conservation Plan Partnership (2016). Criteria 1, 2, and 3a capture species with important population segments in the Great Basin and are common or regular uncommon migrants in the Lahontan Valley (Chisholm and Neel 2002). Criteria 1,2, and 3 b highlight species of national conservation concern that occur regularly in the Lahontan Valley, even if only in small numbers.

\section{RESULTS}

\section{Annual and Seasonal Occurrence}

Twenty-eight shorebird species were recorded during the 34 years of surveys in the Lahontan Valley, 1986-2019 (Table 1). The Black-necked Stilt (Himantopus mexicanus), American Avocet (Recurvirostra americana), and Long-billed Dowitcher were the only species recorded annually in both spring and fall. If most or all Calidris sandpipers had been identified to species (Table 1 ), this likely was also the case for both the Western (C. mauri) and Least ( $C$. minutilla) sandpipers. An additional 11 species were recorded in both spring and fall in $\geq 50 \%$ of the survey years ( $\geq 17$ years); 4 others were recorded in $\geq 50 \%$ of the survey years in just one season. Finally, 10 species were recorded in $<50 \%$ of the survey years in either season.

For both seasons combined, 19 species were recorded in at least 17 years and we treat them as regular in occurrence (Figure 3 ), while the species recorded in $<50 \%$ of the years we consider irregular. Frequency of occurrence for regularly occurring species was similar between seasons (Table 1). Median frequencies of occurrence for the 19 regular species were 27 years in spring and 25 in fall. Among regular species, the Black-bellied Plover (Pluvialis squatarola), Semipalmated Plover (Charadrius semipalmatus), Long-billed Curlew (Numenius americanus), Dunlin (Calidris alpina), and Willet (Tringa semipalmata) were recorded more often ( $\geq 10 \%$ more years) in spring than in fall. The Lesser Yellowlegs (Tringa flavipes), Wilson's Snipe (Gallinago delicata), and Red-necked Phalarope (Phalaropus lobatus) were recorded more often in fall than in spring (Table 1).

\section{Seasonal Abundance by Species}

Maximum seasonal counts exceeded 10,000 individuals for the American Avocet (spring and fall), Least Sandpiper (spring), Western Sandpiper (spring), Long-billed Dowitcher (spring and fall), and Wilson's Phalarope (Phalaropus tricolor; fall). Under the presumption that Western Sandpipers account for many of the unidentified Calidris spp. (Table 1, this study; Chisholm and Neel 2002), this species likely exceeds 10,000 in fall as well as in spring. In addition, maximum counts exceeded 1000 individuals for the Black-necked Stilt and Least Sandpiper in both spring and fall, for the Semipalmated Plover, Long-billed Curlew, and Dunlin in spring, and for the Red-necked Phalarope in fall.

The seasonal patterns of median counts were similar to those of maximum counts (Table 1). Median counts of the American Avocet and Long-billed Dowitcher exceeded 1000 individuals in both spring and fall; of the Blacknecked Stilt only in fall. The Black-necked Stilt, Least Sandpiper, Western 


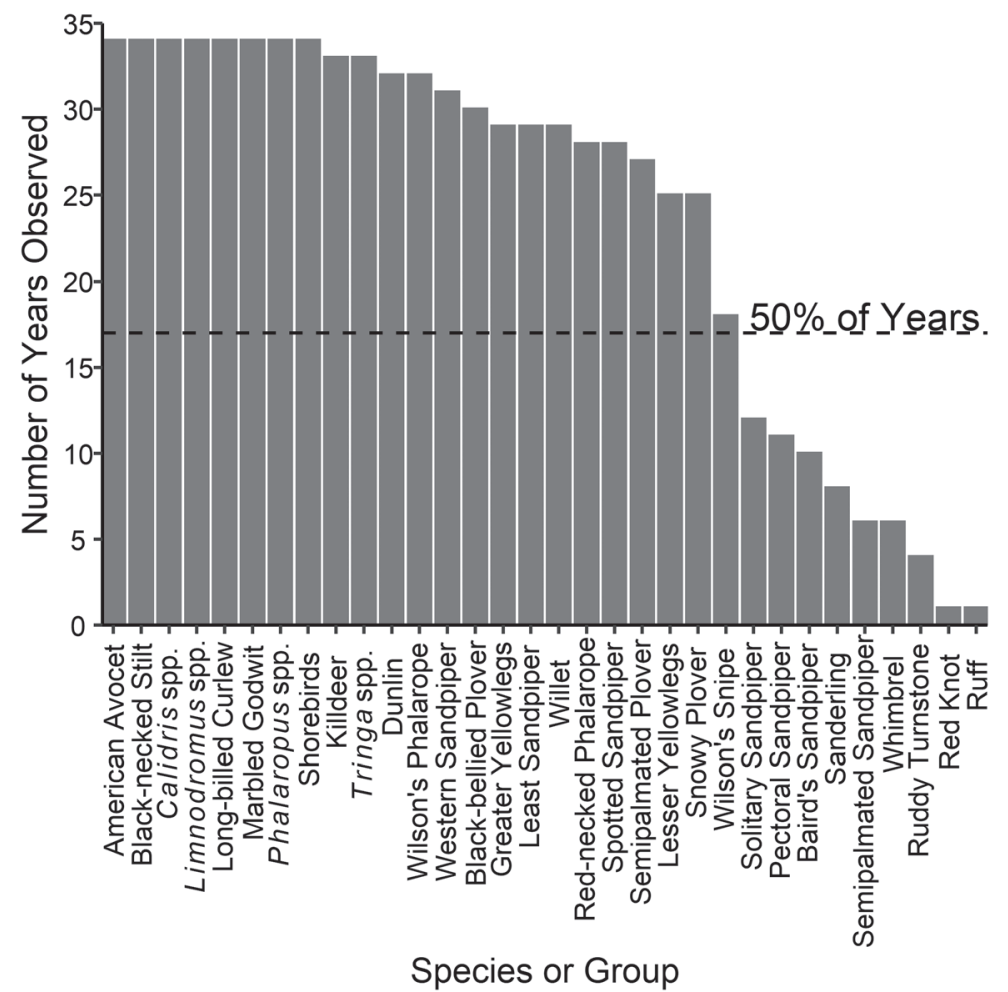

FIgURE 3. Number of years, within the 34-year study period, 1986-2019, in which a species or species group was recorded as present on spring or fall shorebird surveys of the Lahontan Valley wetlands, Nevada.

Sandpiper, and Wilson's Phalarope had median counts of $\geq 100$ in both spring and fall. The Dunlin exceeded that threshold only in spring, whereas the Rednecked Phalarope exceeded it only in fall. Among the 19 regularly observed species, the spring median was higher for 8 and the fall median was higher for 10. The seasonal medians were the same for the Long-billed Curlew (Table 1).

\section{Seasonal and Annual Abundance for All Shorebirds Combined}

Total counts for all shorebirds combined varied by season and year (Table 1, Figure 4). The number of years in which the spring count was higher equaled the number in which the fall count was higher. Total counts in spring exceeded 100,000 individuals in 3 years, 20,000 in 24 years. Fall counts exceeded 100,000 shorebirds in 2 years and 20,000 in 17 years. No seasonal total count after 1991 exceeded 100,000 shorebirds. Spring and fall totals combined by year, annual totals exceeded 100,000 shorebirds in 8 years (most recently in 2001) and 20,000 in 31 years.

Median counts for all shorebirds combined were 30,758 (maximum: 
TABLE 1 Number of Years Reported and Nonzero Median and Maximum Totals by Season for Shorebirds on Surveys of the Lahontan Valley, Nevada, 1986-2019

\begin{tabular}{|c|c|c|c|c|}
\hline \multirow[b]{2}{*}{ Species } & \multicolumn{2}{|c|}{ Spring } & \multicolumn{2}{|c|}{ Fall } \\
\hline & Frequency ${ }^{a}$ & $\begin{array}{c}\text { Median } \\
\text { (Maximum) }\end{array}$ & Frequency $^{a}$ & $\begin{array}{c}\text { Median } \\
\text { (Maximum) }\end{array}$ \\
\hline $\begin{array}{l}\text { Black-necked Stilt Himantopus } \\
\text { mexicanus }\end{array}$ & 34 & $\begin{array}{c}792 \\
(6549)\end{array}$ & 34 & $\begin{array}{c}1489 \\
(8166)\end{array}$ \\
\hline $\begin{array}{l}\text { American Avocet Recurvirostra } \\
\text { americana }\end{array}$ & 34 & $\begin{array}{c}5871 \\
(17,309)\end{array}$ & 34 & $\begin{array}{c}6233 \\
(66,905)\end{array}$ \\
\hline $\begin{array}{l}\text { Black-bellied Plover Pluvialis } \\
\text { squatarola }\end{array}$ & 28 & $\begin{array}{c}77 \\
(386)\end{array}$ & 12 & $\begin{array}{c}4 \\
(25)\end{array}$ \\
\hline Killdeer Charadrius vociferus & 32 & $\begin{array}{c}29 \\
(829)\end{array}$ & 32 & $\begin{array}{c}59 \\
(976)\end{array}$ \\
\hline $\begin{array}{l}\text { Semipalmated Plover } \\
\quad \text { Charadrius semipalmatus }\end{array}$ & 25 & $\begin{array}{c}26 \\
(1800)\end{array}$ & 21 & $\begin{array}{c}12 \\
(47)\end{array}$ \\
\hline $\begin{array}{l}\text { Snowy Plover Charadrius } \\
\text { nivosus }\end{array}$ & 18 & $\begin{array}{c}9 \\
(46)\end{array}$ & 19 & $\begin{array}{c}16 \\
(197)\end{array}$ \\
\hline Whimbrel Numenius phaeopus & 4 & $\begin{array}{c}4 \\
(15)\end{array}$ & 3 & $\begin{array}{c}1 \\
(5)\end{array}$ \\
\hline $\begin{array}{l}\text { Long-billed Curlew Numenius } \\
\text { americanus }\end{array}$ & 33 & $\begin{array}{c}19 \\
(1284)\end{array}$ & 24 & $\begin{array}{c}19 \\
(292)\end{array}$ \\
\hline Marbled Godwit Limosa fedoa & 32 & $\begin{array}{c}71 \\
(583)\end{array}$ & 30 & $\begin{array}{c}48 \\
(555)\end{array}$ \\
\hline $\begin{array}{l}\text { Ruddy Turnstone Arenaria } \\
\text { interpres }\end{array}$ & 1 & $\begin{array}{c}1 \\
(1)\end{array}$ & 3 & $\begin{array}{c}1 \\
(10)\end{array}$ \\
\hline Red Knot Calidris canutus & 1 & $\begin{array}{c}1 \\
(1)\end{array}$ & - & $(-)$ \\
\hline Ruff Calidris pugnax & - & $(-)$ & 1 & $\begin{array}{c}1 \\
(1)\end{array}$ \\
\hline Sanderling Calidris alba & 5 & $\begin{array}{c}1 \\
(22)\end{array}$ & 5 & $\begin{array}{c}2 \\
(3)\end{array}$ \\
\hline Dunlin Calidris alpina & 32 & $\begin{array}{c}560 \\
(9302)\end{array}$ & 13 & $\begin{array}{c}3 \\
(200)\end{array}$ \\
\hline $\begin{array}{l}\text { Baird's Sandpiper Calidris } \\
\quad \text { bairdii }\end{array}$ & 2 & $\begin{array}{c}3 \\
(4)\end{array}$ & 9 & $\begin{array}{c}6 \\
(27)\end{array}$ \\
\hline $\begin{array}{l}\text { Least Sandpiper Calidris } \\
\quad \text { minutilla }\end{array}$ & 27 & $\begin{array}{c}341 \\
(15,323)\end{array}$ & 27 & $\begin{array}{c}147 \\
(2800)\end{array}$ \\
\hline
\end{tabular}

197,594 ) in spring and 24,230 (maximum: 135,132) in fall (Table 1). The median total annual count was 56,648 (maximum: 230,711).

\section{Priority Species}

We evaluated 26 of the 28 species recorded, the rare Red Knot and Ruff excluded. Of the 26 species, 11 met our criteria for being categorized as priority species (Tables 1 and 2). Of these, seven met criteria 1, 2, and 3a: the Black-necked Stilt, American Avocet, Least Sandpiper, Western Sandpiper, Long-billed Dowitcher, Wilson's Phalarope, and Red-necked Phalarope. Four species met criteria 1,2, and 3b: the Snowy Plover (Charadrius nivosus), Longbilled Curlew, Marbled Godwit (Limosa fedoa), and Willet. 


\begin{tabular}{|c|c|c|c|c|}
\hline \multirow[b]{2}{*}{ Species } & \multicolumn{2}{|c|}{ Spring } & \multicolumn{2}{|c|}{ Fall } \\
\hline & Frequency ${ }^{a}$ & $\begin{array}{c}\text { Median } \\
\text { (Maximum) }\end{array}$ & Frequency $^{a}$ & $\begin{array}{c}\text { Median } \\
\text { (Maximum) }\end{array}$ \\
\hline $\begin{array}{l}\text { Pectoral Sandpiper Calidris } \\
\text { melanotos }\end{array}$ & 5 & $\begin{array}{c}3 \\
(8)\end{array}$ & 7 & $\begin{array}{c}2 \\
(20)\end{array}$ \\
\hline $\begin{array}{l}\text { Semipalmated Sandpiper } \\
\text { Calidris pusilla }\end{array}$ & 1 & $\begin{array}{c}1 \\
(1)\end{array}$ & 5 & $\begin{array}{c}1 \\
(2)\end{array}$ \\
\hline $\begin{array}{l}\text { Western Sandpiper Calidris } \\
\text { mauri }\end{array}$ & 27 & $\begin{array}{c}660 \\
(140,074)\end{array}$ & 28 & $\begin{array}{c}571 \\
(8136)\end{array}$ \\
\hline Calidris spp. & 34 & $\begin{array}{c}3886 \\
(162,174)\end{array}$ & 33 & $\begin{array}{c}1748 \\
(18,663)\end{array}$ \\
\hline Limnodromus spp. ${ }^{b}$ & 34 & $\begin{array}{c}14,540 \\
(82,010)\end{array}$ & 34 & $\begin{array}{c}7539 \\
(55,349)\end{array}$ \\
\hline $\begin{array}{l}\text { Wilson’s Snipe Gallinago } \\
\text { delicata }\end{array}$ & 11 & $\begin{array}{c}2 \\
(16)\end{array}$ & 13 & $\begin{array}{c}6 \\
(486)\end{array}$ \\
\hline $\begin{array}{l}\text { Spotted Sandpiper Actitis } \\
\text { macularius }\end{array}$ & 20 & $\begin{array}{c}4 \\
(18)\end{array}$ & 20 & $\begin{array}{c}7 \\
(25)\end{array}$ \\
\hline $\begin{array}{l}\text { Solitary Sandpiper Tringa } \\
\text { solitaria }\end{array}$ & 7 & $\begin{array}{l}2 \\
(6)\end{array}$ & 8 & $\begin{array}{c}1 \\
(4)\end{array}$ \\
\hline $\begin{array}{l}\text { Lesser Yellowlegs Tringa } \\
\text { flavipes }\end{array}$ & 13 & $\begin{array}{c}6 \\
(44)\end{array}$ & 24 & $\begin{array}{c}12 \\
(81)\end{array}$ \\
\hline Willet Tringa semipalmata & 24 & $\begin{array}{c}7 \\
(35)\end{array}$ & 18 & $\begin{array}{c}4 \\
(20)\end{array}$ \\
\hline $\begin{array}{l}\text { Greater Yellowlegs Tringa } \\
\text { melanoleuca }\end{array}$ & 25 & $\begin{array}{c}14 \\
(172)\end{array}$ & 25 & $\begin{array}{c}31 \\
(124)\end{array}$ \\
\hline Tringa spp. & 32 & $\begin{array}{c}34 \\
(145)\end{array}$ & 33 & $\begin{array}{c}72 \\
(321)\end{array}$ \\
\hline $\begin{array}{l}\text { Wilson's Phalarope Phalaropus } \\
\text { tricolor }\end{array}$ & 29 & $\begin{array}{c}100 \\
(2592)\end{array}$ & 31 & $\begin{array}{c}295 \\
(13,776)\end{array}$ \\
\hline $\begin{array}{l}\text { Red-necked Phalarope } \\
\text { Phalaropus lobatus }\end{array}$ & 16 & $\begin{array}{c}23 \\
(505)\end{array}$ & 26 & $\begin{array}{c}792 \\
(5944)\end{array}$ \\
\hline Phalaropus spp. & 32 & $\begin{array}{c}148 \\
(3395)\end{array}$ & 34 & $\begin{array}{c}1659 \\
(21,931)\end{array}$ \\
\hline All shorebirds & 34 & $\begin{array}{c}30,758 \\
(197,594)\end{array}$ & 34 & $\begin{array}{c}24,230 \\
(135,132)\end{array}$ \\
\hline
\end{tabular}

${ }^{a}$ Of 34 years possible.

${ }^{b}$ Treated in the text and analysis as the Long-billed Dowitcher, Limnodromus scolopaceus.

\section{DISCUSSION}

The results and descriptive analysis of 34 years of shorebird surveys at the Lahontan Valley affirm the area's continuing importance to migrant shorebirds. This site is used by a large and diverse assemblage of shorebird species generally consistent with what Shuford et al. (2002) and others (e.g., Oring and Reed 1996) have documented in the Great Basin and more broadly in the Intermountain West.

Shuford et al. (2002) summarized spring and fall counts from 1989 to 1995 at 38 "key" shorebird sites-defined as sites supporting $>1000$ shorebirds in either spring or fall-across the Intermountain West. They recorded 39 species of shorebirds, with the American Avocet being the most numerous, on the 


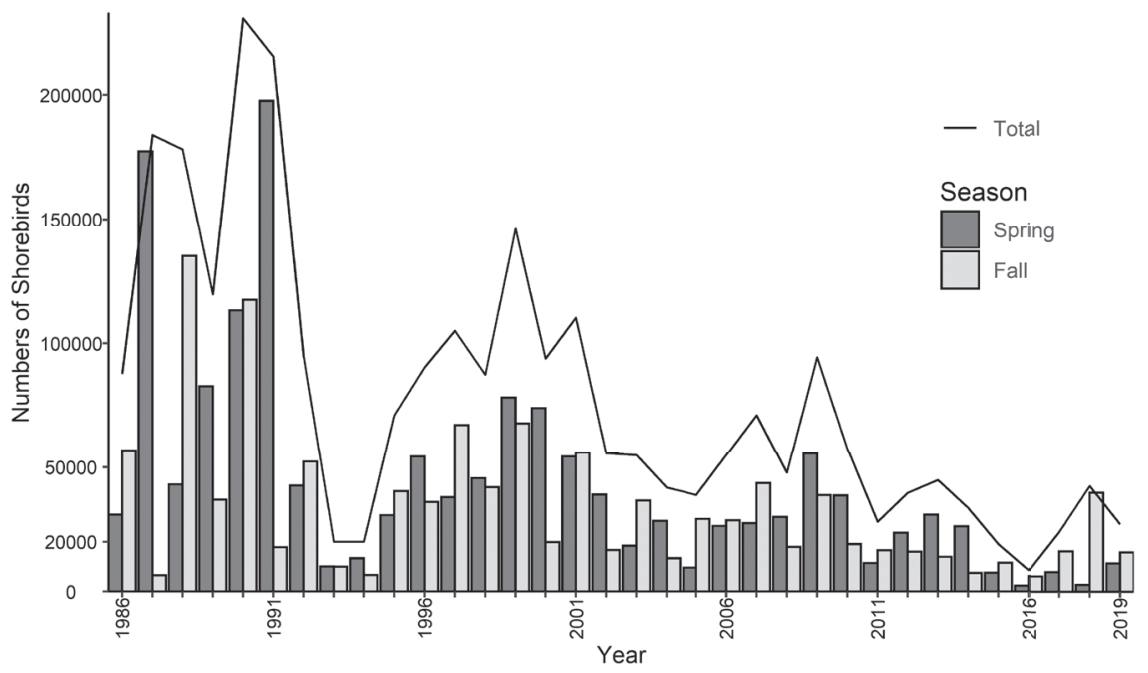

FIgURE 4. Total counts of all shorebirds combined, by season and year, on surveys of the Lahontan Valley wetlands, Nevada, 1986-2019. Solid line is the sum of spring and fall counts for each year.

basis of median and maximum counts. In the Lahontan Valley, 1986-2019, we recorded 28 species, with the Long-billed Dowitcher being most numerous, followed closely by American Avocet. After the Great Salt Lake and Salton Sea, the two sites with the greatest numbers of shorebirds, Shuford et al. (2002) placed the Lahontan Valley among only eight other sites with $>10,000$ birds in either spring or fall. According to the results of the surveys we describe here, the Lahontan Valley exceeded that threshold in either spring or fall in 33 of 34 years (Figure 4). Including the Lahontan Valley, 7 of the 10 sites identified by Shuford et al. (2002) as having the great numbers of shorebirds were in the western Great Basin.

Shuford et al. (2002) recorded 14 species on $\geq 50 \%$ of all spring or fall surveys across the Intermountain West; 8 of those species were recorded on $\geq 50 \%$ of all surveys during both seasons. In the Lahontan Valley, we recorded 19 species in $\geq 50 \%$ of all years, 14 of them in both seasons. Of these 19 species, 5 did not reach that threshold across the Intermountain West in the surveys summarized by Shuford et al. (2002): the Black-bellied Plover, Snowy Plover, Long-billed Curlew, Marbled Godwit, and Wilson's Snipe. Three of these five species are ranked as of greatest (Snowy Plover) or high (Long-billed Curlew, Marbled Godwit) conservation concern by the U.S. Shorebird Conservation Plan Partnership (2016).

For total shorebirds, Shuford et al. (2002) recorded a fall median 2.5 times higher than the spring median (fall 670,953; spring 271,902). This high fall median was driven by large numbers of species such as the American Avocet and Wilson's Phalarope that gather in fall migration at hypersaline lakes like the Great Salt Lake (e.g., Sorenson et al. 2020). In the Lahontan Valley, median seasonal counts for all shorebirds combined were similar but higher in spring 
TABLE 2 Estimated Populations, Regional Importance, and National Level of Conservation Concern of 26 Species of Shorebirds in the Lahontan Valley, Nevada

\begin{tabular}{|c|c|c|c|c|c|}
\hline \multirow[b]{2}{*}{ Species } & \multicolumn{2}{|c|}{ Biogeographic population $^{a}$} & \multirow[b]{2}{*}{$\begin{array}{c}\text { BCR 9/ } \\
\text { Great Basin } \\
\text { population }^{b}\end{array}$} & \multirow[b]{2}{*}{$\begin{array}{c}\text { BCR 9/ } \\
\text { Great Basin } \\
\text { importance }^{c}\end{array}$} & \multirow[b]{2}{*}{$\begin{array}{l}\text { Level of } \\
\text { conservation } \\
\text { concern }^{d}\end{array}$} \\
\hline & $\begin{array}{l}\text { Segment of species } \\
\text { to which estimate } \\
\text { applies }\end{array}$ & Estimate & & & \\
\hline Black-necked Stilt & H. m. mexicanus & 550,000 & 119,500 & 5 & least \\
\hline American Avocet & entire species & 450,000 & 411,500 & 5 & moderate \\
\hline Black-bellied Plover & P. s. squatarola & 262,700 & 15,000 & 4 & moderate \\
\hline Snowy Plover & C.n.nivosus & 22,900 & 8800 & 5 & greatest \\
\hline Semipalmated Plover & entire species & 200,000 & 2800 & 3 & least \\
\hline Killdeer & entire species & $2,000,000$ & 47,400 & 4 & moderate \\
\hline Whimbrel & N.p. rufiventris & 40,000 & 700 & 3 & high \\
\hline Long-billed Curlew & entire species & 140,000 & 47,800 & 5 & high \\
\hline Marbled Godwit & L.f. fedoa & 172,000 & 128,700 & 4 & high \\
\hline Ruddy Turnstone & $\begin{array}{c}\text { Alaska population } \\
\text { of } A \text {. i. interpres }\end{array}$ & 20,000 & $200 ?$ & 2 & moderate \\
\hline Sanderling & entire species & 300,000 & 14,900 & 3 & moderate \\
\hline Dunlin & C. a.pacifica & 550,000 & 25,000 & 3 & moderate \\
\hline Baird's Sandpiper & entire species & 300,000 & 6300 & 4 & least \\
\hline Least Sandpiper & entire species & 700,000 & 96,900 & 4 & least \\
\hline Pectoral Sandpiper & entire species & $1,600,000$ & 900 & 3 & high \\
\hline $\begin{array}{l}\text { Semipalmated } \\
\text { Sandpiper }\end{array}$ & entire species & $2,260,000$ & 200 & 3 & high \\
\hline Western Sandpiper & entire species & $3,500,000$ & 491,400 & 5 & moderate \\
\hline $\begin{array}{l}\text { Long-billed } \\
\text { Dowitcher }\end{array}$ & entire species & 500,000 & 243,500 & 5 & moderate \\
\hline Wilson’s Snipe & entire species & $2,000,000$ & $?$ & 4 & least \\
\hline Spotted Sandpiper & entire species & 660,000 & 9700 & 4 & least \\
\hline Solitary Sandpiper & T. s. cinnamomea & 63,000 & 2600 & 3 & least \\
\hline Greater Yellowlegs & entire species & 137,000 & 10,300 & 3 & least \\
\hline Willet & T. s. inornata & 160,000 & 49,500 & 5 & high \\
\hline Lesser Yellowlegs & entire species & 660,000 & 11,500 & 3 & high \\
\hline Wilson's Phalarope & entire species & $1,500,000$ & 711,100 & 5 & least \\
\hline $\begin{array}{l}\text { Red-necked } \\
\text { Phalarope }\end{array}$ & entire species & $2,500,000$ & 349,700 & 5 & moderate \\
\hline
\end{tabular}

${ }^{a}$ Sources: whsrn.org/why-whsrn/is-my-site-eligible/, Andres et al. (2012).

bSources: Thomas et al. (2013), B. Andres (pers. comm.). Estimates rounded to nearest 100.

${ }^{c} 5$, Critical for supporting the species in the entire Western Hemisphere; 4, important to supporting hemispheric or regional populations; 3 , species occurs regularly within the region but in low abundance; and 2, species within its normal range, but in general management for it is not warranted. Sources: Thomas et al. (2013), B. Andres (pers. comm).

${ }^{d}$ Source: U.S. Shorebird Conservation Plan Partnership (2016).

$(30,758)$ than in fall $(24,230)$. Although median values for the American Avocet and Wilson's Phalarope in the Lahontan Valley were higher in the fall than in spring, large numbers of Long-billed Dowitchers and Calidris sandpipers account for the overall median being higher in spring.

Numbers of shorebirds using the Lahontan Valley annually are undoubt- 
edly higher than those recorded on the surveys we describe. Spring and especially fall movements of shorebirds through the Lahontan Valley are spread over several months, and single surveys within each season capture only snapshots of shorebirds passing through over time. Even though these surveys were intended to be carried out during periods of peak shorebird migration, patterns for individual species vary and significant numbers likely were missed. For example, because most fall surveys were conducted in August, we likely missed many Wilson's and Red-necked Phalaropes, which start to peak in July, and Dunlins, which do not arrive until late September (Chisholm and Neel 2002). Furthermore, hard-to-detect species like Wilson's Snipe are likely underrepresented, and specially designed surveys would be required to improve their detection (Warnock et al. 1998).

When the Lahontan Valley wetlands were designated as a WHSRN site in 1988, a number of shorebirds $>250,000$ was the criterion for defining a site as of hemispheric importance. In 1990, however, the WHSRN criteria were revised as follows: 500,000 shorebirds annually or $30 \%$ of a species' biogeographic population for hemispheric status; 100,000 shorebirds annually or $10 \%$ of a biogeographic population for international status; or 20,000 shorebirds annually or $1 \%$ of a biogeographic population for regional status (whsrn.org/why-whsrn/is-my-site-eligible/).

Annual totals in the Lahontan Valley exceeded the WHSRN criteria of 100,000 and 20,000 shorebirds in $24 \%$ and $94 \%$ of the survey years, respectively (Figure 4). The maximum number of American Avocets recorded in any season $(66,905)$ was about $15 \%$ of the estimated global population, and annual totals of this species were $\geq 10 \%$ (45,000 individuals) of the global population in three years (Tables 1 and 2, Figure 5). The maximum number of Long-billed Dowitchers recorded in any season $(82,010)$ was about $18 \%$ of the global population, and annual totals of this species were $\geq 10 \%(50,000)$ in two years. In addition, the number of Long-billed Dowitchers was $\geq 10 \%$ $(25,000)$ of the Pacific Americas Flyway population in 19 years (B. Andres pers. comm.). Consideration of turnover rates and birds missed because of the number, nature, and timing of the surveys would increase these numbers and proportions.

Applying the current WHSRN criteria to these data on annual counts and biogeographic populations affirms the continued importance of the Lahontan Valley wetlands as a site of regional or international importance, but not of hemispheric importance. Reclassifying the site's status would ensure consistency of the Lahontan Valley wetlands with WHSRN sites designated since 1990.

The total annual counts were highest from 1987 to 1991, and all 8 years in which the total annual counts exceeded 100,000 shorebirds fell during the interval 1987-2001 (Figure 4). A visual examination of the data suggests that use of the Lahontan Valley by shorebirds is declining, but given the variability or uncertainty in observer numbers, survey methods, effort, and coverage, the apparent trend may not be real. If the apparent decline is real, several possible explanations, either singly or in combination, may apply.

Declines in regional or continental shorebird populations (Rosenberg et al. 2019) ultimately will be manifest at local scales. For example, the Alaska Shorebird Group (2019) considered the Western Sandpiper to be declining 


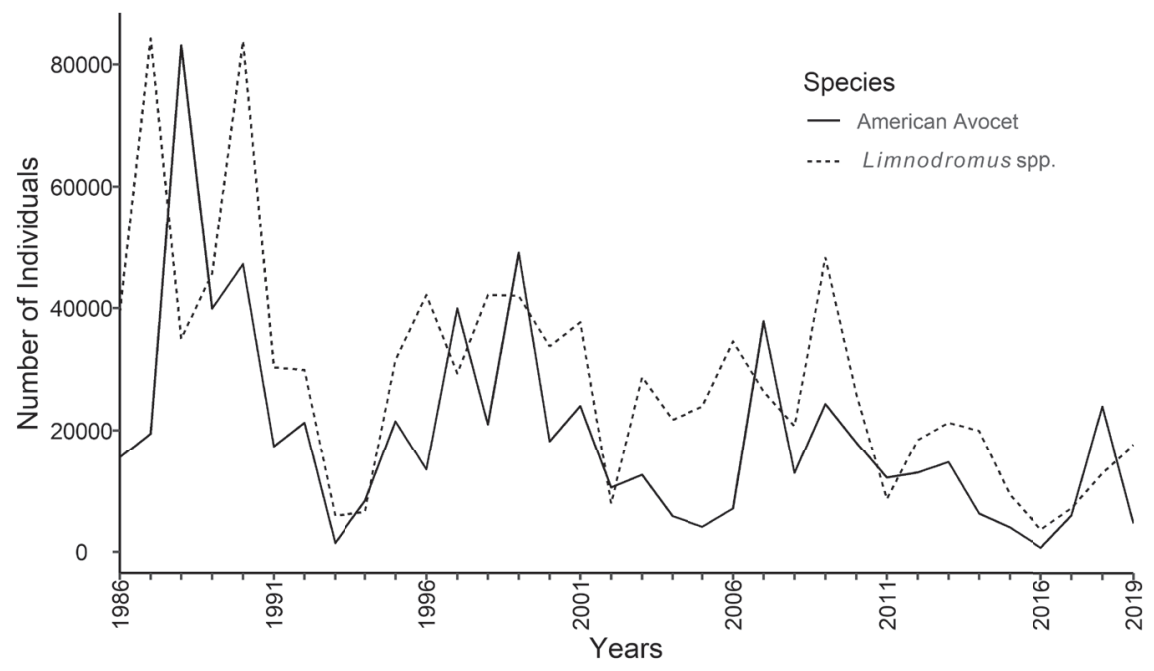

FIgURe 5. Annual totals (sum of spring and fall counts by year) for dowitchers (overwhelmingly Long-billed Dowitchers) and the American Avocet on surveys of the Lahontan Valley wetlands, Nevada, 1986-2019.

on its breeding grounds, and Warnock et al. (2021) documented long-term declines in the numbers of Western Sandpipers at Tomales Bay in coastal California. The declines at Tomales Bay were recorded from 1989 to 2019, essentially concurrent with our surveys and the apparent decline in numbers of Western Sandpipers in the Lahontan Valley.

Changes in the availability of water and wetland habitats at regional scales also may influence shorebird use of the Lahontan Valley. For example, comparing 1972-1993 with 1998-2015, Stenzel and Page (2018) related increased fall flooding of rice fields in California's Central Valley in the 1990s with changes in use by waterbirds of a coastal site, Bolinas Lagoon. The American Avocet and dowitchers were among the shorebirds whose numbers at Bolinas Lagoon declined during the latter period, as they also appear to have done in the Lahontan Valley. There may or may not be a connection for these species between the Central Valley and Lahontan Valley, but changes in water use elsewhere in the region could affect numbers of these and other shorebirds in the Lahontan Valley similarly.

Finally, there have been major changes in the availability and seasonality of water and wetland habitats in the Lahontan Valley. Neel and Henry (1996) described the influence of fluctuating water levels-locally and regionally-on annual shorebird use of the Lahontan Valley (also see Shuford et al. 2002). For example, exceptionally large numbers of Long-billed Dowitchers were recorded in spring 1987, as water receded from flood conditions in the previous year (Neel and Henry 1986). Carson Lake was completely dry in 2015 and in spring 2016, and it was completely flooded in 2017. Hence annual total counts of shorebirds from 2015 to 2017 were very low (Figure 
4). Too little or too much water, as well as changes in the timing of the availability of water, are undoubtedly influencing shorebirds' use of the Lahontan Valley. Unfortunately, the distribution and timing of water in the Lahontan Valley are now so altered and complex that there are no simple proxies, such as snowmelt or precipitation, to characterize each year's water conditions. Improved design and implementation of shorebird surveys and tracking of water conditions are needed for the interplay of shorebirds and water at local and regional scales to be better understood.

Despite the WHSRN designation, system-wide or site-specific management requirements for maintaining shorebird habitat and use of the Lahontan Valley wetlands have not been defined. The Nevada Department of Wildlife and its partners and stakeholders will need to address these issues in the development of a new management plan for Carson Lake. The wetland ecosystem is the primary resource of concern at Stillwater NWR, and refuge staff have identified shorebird populations and habitat characteristics as indicators of wetland health (USFWS 2020). More than three decades after the Lahontan Valley's designation as a WHSRN site, it is timely for NDOW, USFWS, and others to jointly revisit management objectives and practices for the entire wetland complex.

The requirements of priority species we have identified can be used to evaluate and shape habitat and water management for migrant shorebirds. It is beyond the scope of this paper to parse species-specific requirements, but in the Lahontan Valley shorebirds use a range of habitats, including open, standing water of several centimeters or more in depth (e.g., phalaropes and American Avocet), shallow water and adjacent open mudflats or edge habitats with interspersed vegetation (e.g., dowitchers and Calidris spp.), playas or salt flats (Snowy Plover), and grasslands (Long-billed Curlew) (Chisholm and Neel 2002). Several of these priority species, such as the Snowy Plover, American Avocet, Long-billed Curlew, and Wilson's Phalarope, also nest in the Lahontan Valley (Chisholm and Neel 2002, Young and Oring 2006) and have different or additional habitat requirements to be considered during the breeding season.

Establishing priorities for habitat and water management can be complex, especially when multiple values and uses must be considered (e.g., irrigation for agriculture, nesting wading birds in the summer, and waterfowl hunting in the fall). However, we offer the following recommendations for enhancing management for shorebirds in the Lahontan Valley, including at Carson Lake, which, under federal law (P.L. 101-618, Title II), must be managed "consistent" with its WHRSN designation:

- Build profiles of priority species, including timing of use and seasonal habitat requirements, such as water depth and vegetation types (see Jones et al. 2016 for the Salton Sea).

- Review management practices and identify areas where there are opportunities to manage water quantity and quality, vegetation, grazing, or other factors to benefit shorebirds.

- Explicitly incorporate shorebirds' habitat requirements and quantitative objectives for their use of the site into site- and unit-management plans. Establish numerical objectives that trigger increased levels of 
concern and management when these objectives for shorebird numbers are not met (see Tavernia et al. 2017).

- Reassess current methods and coverage for shorebird surveys and habitat characterization and implement a consistent, rigorous approach to facilitate statistical analyses of population trends, timing of shorebird occurrence, and progress toward habitat-management objectives (e.g., see recommendations in PRISM 2018 and Reiter et al. 2020).

- Coordinate survey and management efforts, including allocation of water across management units, and meet regularly with stakeholders on an interagency basis to plan for and evaluate progress toward integrated area-wide management goals.

- Upgrade the water-management infrastructure to enhance the refuges' ability to allocate and manage water across the wetland complex.

- Repeat some version of the synoptic surveys described by Shuford et al. (2002) throughout the Intermountain West to provide regional context for interpretation of the results of surveys of the Lahontan Valley and to further the understanding of the status and trends of shorebird populations overall.

Continuing declines in surface water and wetlands in the Lahontan Valley and Great Basin as a whole (Donnelly et al. 2020) give urgency to these recommendations, as does the decline of shorebird numbers more broadly in North America (Rosenberg et al. 2019). Shuford et al. (2002), Thomas et al. (2013), and Senner et al. (2016) highlighted the need for coordinated action at regional and flyway scales. Maintaining habitat for shorebirds in the Lahontan Valley is essential to the success of these larger endeavors.

\section{ACKNOWLEDGMENTS}

We thank NDOW for providing access to its shorebird survey data via a datasharing agreement with the National Audubon Society. Of the many people who surveyed shorebirds in the Lahontan Valley, we especially thank Graham Chisholm, Mike Goddard, and Bill Henry. Dan Scheiman entered the data from recent years into the database. Brad Andres, Joe Barnes, and Laura Chamberlin read several drafts of the manuscript. In addition to the authors, the following individuals participated in a March 2020 workshop reviewing protocols for the Lahontan Valley shorebird surveys: Elisabeth Ammon, Brad Andres, Joe Barnes, Jonathan Garrison, Mike Goddard, Kayla Henry, and Carl Lunderstadt. This workshop informed the survey analysis and recommendations presented here. Finally, Vanessa Loverti, Dave Shuford, and Nils Warnock provided constructive comments on a draft of the manuscript.

\section{LITERATURE CITED}

Alaska Shorebird Group. 2019. Alaska Shorebird Conservation Plan, version III. Alaska Shorebird Group, Anchorage, AK; www.fws.gov/alaska/pages/migratory-birds/shorebirds.

Andres, B. A., Smith, P. A., Morrison, R. I. G., Gratto-Trevor, C. L., Brown, S. C., and Friis, C. A. 2012. Population estimates of North American shorebirds, 2012. Wader Study Group Bull. 119:178-194.

Bundy, R. 2001. Nomination of the Lahontan Valley wetlands, Nevada, U.S.A., as wetlands of international importance under the Ramsar Convention. Application submitted to the Ramsar Convention Secretariat. Stillwater Natl. Wildlife Ref., 1020 New River Pkwy., \#305, Fallon, NV 89406. 
Chisholm, G., and Neel, L. A. 2002. Birds of the Lahontan Valley: A Guide to Nevada's Wetland Oasis. Univ. of Nev. Press, Reno.

Donnelly, J. P., King, S. L., Silverman, N. L., Collins, D. P., Carrera-Gonzalez, E. M., Lafón-Terrazas, A., and Moore, J. N. 2020. Climate and human water use diminish wetland networks supporting continental waterbird migration. Glob. Change Biol. 4:2042-2059; doi.org/10.1111/gcb.15010.

Haig, S. M., Murphy, S. P., Matthews, J. H., Arismendi, I., and Safeeq, M. 2019. Climate-altered wetlands challenge waterbird use and migratory connectivity in arid landscapes. Sci. Rep. 9:4666; doi.org/10.1038/s41598-019-41135-y.

Jehl, J. R. Jr. 1994. Changes in saline and alkaline lake avifaunas in western North America over the past 150 years. Studies Avian Biol. 15:258-272.

Jones, A., Krieger, K., Salas, L., Elliott, N., and Cooper, D. S. 2016. Quantifying bird habitat at the Salton Sea: Informing the state of California's Salton Sea Management Plan. Report to the Calif. Natural Resources Agency. Audubon California, Point Blue Conservation Science, and Cooper Ecological Monitoring, Inc.; ca.audubon.org/sites/default/files/salton_sea_habitat_modeling_technical_report_-_final_0.pdf.

Kerley, L. L., Ekechukwu, E. L., and Hallock, R. J. 1993. Estimated historical conditions of the lower Carson River wetlands, in Part B, Effect on biota in Stillwater and Fernley wildlife management areas and other nearby wetlands. Detailed study of irrigated drainage in and near wildlife management areas, west-central Nevada, 1987-1990 (R. J. Hallock and L. L. Hallock, eds.), pp. 7-20. U.S. Geol. Surv. Water-Resources Invest. Rep. 92-4024B.

Moore, J. N. 2016. Recent desiccation of western Great Basin saline lakes: Lessons from Lake Abert, Oregon, USA. Sci. Total Environ. 554:142-154; doi. org/10.1016/j.scitotenv.2016.02.161.

Neel, L. A., and Henry, W. G. 1996. Shorebirds of the Lahontan Valley, Nevada, USA: A case history of western Great Basin shorebirds. Int. Wader Studies 9:15-19.

Nevada Department of Wildlife (NDOW). 1988. Stillwater hemispheric reserve, Nevada, USA. Lahontan Valley wetlands nomination package. Western Hemisphere Shorebird Reserve Network, P.O. Box 1770, Manomet, MA 02345.

Oring, L. W., and Reed, J. M. 1996. Shorebirds of the western Great Basin of North America: Overview and importance to continental populations. Int. Wader Studies 9:6-12.

Oring, L. W., Neel, L., and Oring, K. E. 2000. Intermountain West regional shorebird plan, version 1.0. Regional plan of the U.S. Shorebird Conservation Partnership; www.shorebirdplan.org/regional-shorebird-conservation-plans/.

Page, G. W., and Gill, R. E., Jr. 1994. Shorebirds in western North America: Late 1800s to late 1900s. Studies Avian Biol. 15:147-160.

Program for Regional and International Shorebird Monitoring (PRISM). 2018. Standards for monitoring nonbreeding shorebirds in the Western Hemisphere. Program for Regional and International Shorebird Monitoring (PRISM); www. shorebirdplan.org/science/program-for-regional-and-international-shorebirdmonitoring/.

Reiter, M., Palacios, E., Eusse-Gonzalez, D., Johnston González, R., Davidson, P., Bradley, D., Clay, R., Strum, K., Chu, J., Barbaree, B., and Hickey, C. 2020. A monitoring framework for assessing threats to nonbreeding shorebirds on the Pacific coast of the Americas. Avian Conserv. Ecol. 15(2); doi.org/10.5751/ ACE-01620-150207.

Rosenberg, K. V., Dokter, A. M., Blancher, P. J., Sauer, J. R., Smith, A. C., Smith, P. A., Stanton, J. C., Panjabi, A., Helft, L., Parr, M., and Marra, P. P. 2019. Decline of the North American avifauna. Science 366:120-124; doi.org/10.1126/science.aaw1313.

Senner, S. E., Andres, B. A., and Gates, H. R. (eds.). 2016. Pacific America shorebird 
conservation strategy. Natl. Audubon Soc., New York; pacificflywayshorebirds. org/downloads/PASCSv2_english_final.pdf

Senner, N. R., Moore, J. N., Seager, S. T., Dougill, S., Kreuz, K., and Senner, S. E. 2018. A salt lake under stress: The relationship between birds, water levels, and invertebrates at a Great Basin saline lake. Biol. Conserv. 220:320-329; doi. org/10.1016/j.biocon.2018.02.003.

Shuford, W. D., Page, G. W., and Stenzel, L. E. 2002. Patterns of distribution and abundance of migratory shorebirds in the Intermountain West of the United States. W. Birds 33:134-174.

Sorensen, E. D., Hoven, H. M., and Neill, J. 2020. Great Salt Lake shorebirds, their habitats and food base, in Great Salt Lake Biology: A Terminal Lake in a Time of Change (B. K. Baxter and J. K. Butler, eds.), pp. 263-309. Springer, Cham, Switzerland; doi.org/10.1007/978-3-030-40352-2_9.

Stenzel, L. E., and Page, G. W. 2018. Trends in abundance of wintering waterbirds relative to rainfall patterns at a central California estuary, 1972-2015, in Trends and traditions: Avifaunal change in western North America (W. D. Shuford, R. E. Gill Jr., and C. M. Handel, eds.), pp. 236-257. Studies of Western Birds 3. W. Field Ornithol., Camarillo, CA; doi 10.21199/SWB3.13.

Tavernia, B. G., Stanton, J. D., and Lyons, J. E. 2017. Integrated wetland management for waterfowl and shorebirds at Mattamuskeet National Wildlife Refuge, North Carolina: U.S. Geol. Surv. Open-File Report 2017-1052; doi.org/10.3133/ ofr20171052.

Thomas, S., Andres, B., and Vest, J. 2013. Shorebirds, in Intermountain West Joint Venture 2013 implementation plan: Strengthening science and partnerships, pp. 5.2-5.30. Intermountain West Joint Venture, Missoula, MT; iwjv.org/ resource/2013-implementation-plan-chapter-5-shorebirds.

U.S. Fish and Wildlife Service (USFWS). 2002. Final environmental impact statement for the Stillwater National Wildlife Refuge Complex comprehensive conservation plan and boundary revision, Churchill and Washoe counties, Nevada. Stillwater National Wildlife Refuge Complex, 1020 New River Parkway, Suite 305, Fallon, NV 89406.

U.S. Fish and Wildlife Service (USFWS). 2020. Priority resources of concern and conservation of the wetland ecosystem at Stillwater and Fallon national wildlife refuges. National Wildlife Refuge System, Pacific Southwest Region, Inventory and Monitoring Initiative, 2800 Cottage Way, Sacramento, CA 95825.

U.S. Shorebird Conservation Plan Partnership. 2016. U.S. Shorebirds of Conservation Concern-2016; www.shorebirdplan.org/wp-content/uploads/2016/08/ Shorebirds-Conservation-Concern-2016.pdf.

Warnock, N., Haig, S. M., and Oring, L. W. 1998. Monitoring species richness and abundance of shorebirds in the western Great Basin. Condor 100:589-600; doi. org/10.2307/1369741.

Warnock, N., Jennings, S., Kelly, J. P., Condeso, T. E., and Lumpkin, D. 2021. Declining winter shorebird populations at a temperate estuary in California: A 30-year perspective. Ornithol. Appl. 123:1-19.

Wilsey, C. B., Taylor, L., Michel, N., and Stockdale, K. 2017. Water and birds in the arid West: Habitats in decline. Natl. Audubon. Soc., New York; nas-nationalprod.s3.amazonaws.com/wbaw_report_5july17_updated.pdf.

Wurtsbaugh, W. A., Miller, C., Null, S. E., DeRose, R. J., Wilcock, P., Hahnenberger, M., Howe, F., and Moore, J. 2017. Decline of the world's saline lakes. Nat. Geosci. 10: 816-821; doi.org/10.1038/ngeo3052.

Young, R. B., and Oring, L. W. 2006. Long-billed Curlew (Numenius americanus) breeding at Carson Lake, Nevada. Great Basin Birds 8:16-20. 